\title{
Mutational Spectrum of Breast Cancer Susceptibility Genes among Women in Northeast Brazil
}

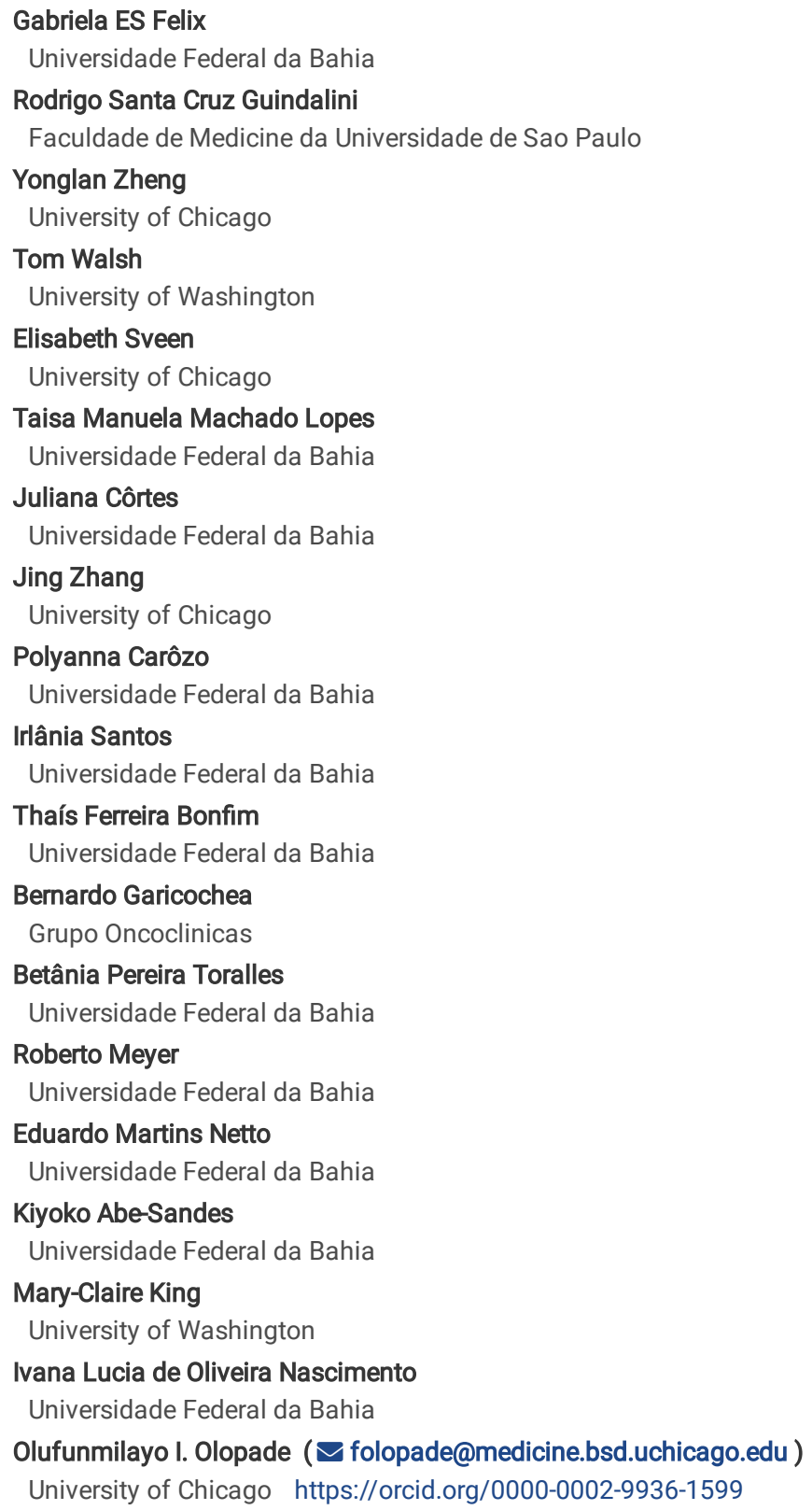

Research Article

Keywords: Breast cancer, Brazilians, BROCA panel, Genetic testing

Posted Date: November 30th, 2021

DOI: https://doi.org/10.21203/rs.3.rs-1065243/v1

License: @) (1) This work is licensed under a Creative Commons Attribution 4.0 International License. Read Full License 


\section{Abstract}

Purpose: There is a paucity of data on the spectrum and prevalence of pathogenic variants among women of African ancestry in the Northeast region of Brazil.

Methods: We performed BROCA panel sequencing to identify inherited loss-of-function variants in breast cancer susceptibility genes among 292 Brazilian women referred to a single institution cancer risk assessment program.

Results: The study included a convenient cohort of 173 women with invasive breast cancer and 119 women who were cancer-free at the time of ascertainment. The majority of the women self-reported as African-descended ( $67 \%$ for cases and $90.8 \%$ for controls). Thirty-seven pathogenic variants were found in $36(20.8 \%)$ patients. While the spectrum of pathogenic variants was heterogeneous, the majority $(70.3 \%)$ of the pathogenic variants were detected in high-risk genes BRCA1 , BRCA2 , PALB2 , and TP53 . Pathogenic variants were also found in the ATM , BARD1 , BRIP1 , FAM175A , FANCM , NBN , and SLX4 genes in $6.4 \%$ of the affected women. Four recurrent pathogenic variants were detected in 11 patients of African ancestry. Only one unaffected woman had a pathogenic variant in the RAD $51 \mathrm{C}$ gene.

Conclusion: The high prevalence and heterogenous spectrum of pathogenic variants identified among self-reported African descendants in Northeast Brazil is consistent with studies in other African populations with a high burden of aggressive young onset breast cancer. It underscores the need to integrate comprehensive cancer risk assessment and genomic testing in the management of newly diagnosed Black women with breast cancer across the African Diaspora, enabling improved cancer control in admixed underserved and understudied populations.

\section{Introduction}

Breast cancer is the most commonly diagnosed cancer among women worldwide [1]. This non-communicable disease is the leading cause of female deaths in many countries, with widening disparities in outcomes among developed and developing countries. Geographic differences in incidence and mortality are due to many intrinsic (e.g. genetic) and extrinsic (e.g. environment, lifestyle) factors [2]. Despite notable differences, "one-size-fits-all" cancer control strategies are usually applied in screening and treatment within and across countries, which have led to widening disparities in breast cancer mortality and morbidity among different racial/ethnic groups [3].

This rising global burden of breast cancer in low- to middle-income countries demands innovative interventions to accelerate progress in cancer control and prevention. Through genomic analysis of breast cancer predisposition genes, the burden of inherited susceptibility to breast cancer in diverse populations can be better estimated, allowing clinical management and treatment recommendations to be tailored to the needs of high-risk women and their families [4]. With advances in high-throughput sequencing technologies, it is now possible to analyze numerous genomic regions simultaneously at greatly reduced cost. Many multi-gene panels such as the BROCA panel have been developed and applied successfully in large genetic testing studies in the United States and Europe [5, 6]. We previously reported the high prevalence of highly penetrant pathogenic variants in BRCA1, BRCA2, PALB2 and TP53 genes in consecutive women presenting with advanced breast cancer at tertiary hospitals in Nigeria, Cameroon and Uganda [7, 8].

Black women across the African Diaspora have the worst outcomes from breast cancer of all ethnic/racial groups. Given the reported high prevalence of aggressive breast cancer in young Brazilian women [9], we sought to examine the burden of inherited breast cancer in a convenient sample of consecutive women with breast cancer ascertained in a cancer risk clinic in the State of Bahia in the Northeast region of Brazil. This region has a large population of African descendants as it remains segregated and is primarily inhabited by former descendants of slaves. The African ancestral proportion revealed through genomic admixture studies is the highest in this region in comparison to other regions of Brazil [10].

\section{Methods}

Study population and eligibility

Between 2008 and 2015, we recruited women with breast cancer referred by their primary care physicians to the Cancer Risk Assessment Program of the Serviço de Oncogenética of Laboratório de Imunologia e Biologia Molecular (ICS-UFBA). This program is supported by Brazilian government agencies and aims to provide genetic counseling to women diagnosed with breast cancer as well their relative(s) if available. To develop a reference panel to improve interpretation of our findings, we recruited a cohort of cancer-free women who were undergoing routine laboratory tests in the same laboratory between 2014 and 2015

All participants signed informed consents, and data regarding their epidemiological and clinical profiles were collected along with questionnaires administered by a research coordinator. The research protocol \#1.383.884 was approved by the Brazilian National Committee of Ethics in Research (CONEP, Comissão Nacional de Ética em Pesquisa), the University of Chicago, and the University of Washington, where the sequencing was performed.

\section{Comprehensive breast cancer risk assessment}

To obtain detailed family history and complete epidemiological information, genetic counselors administered questionnaires after obtaining informed consent. A trained interviewer obtained data from the cancer-free women. We estimated breast cancer risk using online calculators: the Myriad Risk calculator [11], the PENN II Risk Model [12], and BRACAPRO [13], based on the BRCA1 and BRCA2 mutational profiles and clinical and epidemiological data obtained by the genetic counselors during interviews with the breast cancer cases. Upon review of clinical data to verify (a) availability of age of diagnosis or age at enrollment in the study, (b) type of cancer, (c) pathology report, (d) personal and familial history of cancer, (e) place of birth, and (f) DNA sample quality, a total of 173 women with breast cancer (cases) and 119 cancer-free women were included in this study. 
The genomic DNA was extracted from peripheral blood using a commercial kit, the DNeasy ${ }^{\circledR}$ blood and tissue kit (QIAGEN, German). The quality and quantity of the genomic DNA was assessed with $2 \%$ agarose gel electrophoresis analysis and the Quant-iT ${ }^{T M}$ PicoGreen ${ }^{\text {TM }}$ dsDNA Assay Kit (Invitrogen, Thermo Scientific, USA). A total of 28 susceptibility genes were analyzed in the BROCA panel. Genes sequenced included established breast cancer genes of both high and moderate penetrance, and genes that have been suggested as candidate breast cancer genes, with varying levels of evidence: $A T M, A T R, B A P 1, B A R D 1$, BRCA1, BRCA2, BRIP1, CDH1, CHEK1, CHEK2, CTNNA1, FAM175A, FANCM, GEN1, MRE11A, NBN, PALB2, PPM1D, PTEN, RAD51B, RAD51C, RAD51D, RECQL, RINT1, SLX4, STK11, TP53 and XRCC2.

Paired-end reads were mapped to the human genome reference hg19. Subsequently, single nucleotide variants and small insertions and deletions were called as previously described in detail [5, 14], and copy number variants were detected as well [15]. Only variants that led to a loss of gene function or were experimentally demonstrated to damage gene function were included in further analyses. Interpretations of possible splice variants were based on in silico algorithms or on experimental results from our own work or that of others.

\section{Statistical analysis}

Descriptive analysis was performed using Epi Info'm software (CDC, Atlanta, GA, USA) and SPSSÒ (SPSS Inc. Chicago, IL, USA). A non-parametric KruskalWallis test was employed to assess the median differences of the three breast cancer risk calculators between pathogenic variant carriers and non-carriers. The area under the receiver operating characteristic (ROC) curve (AUC) was calculated to evaluate the performance of the risk prediction tools to distinguish high-risk individuals.

\section{Results}

\section{Clinical characteristics}

Over $90 \%$ of the study participants were from the Northeast region of Brazil, particularly from the State of Bahia. About $67.0 \%$ of the breast cancer case selfreported as African-descended (Black), with enriched family history of cancer, including breast cancer ( 65\%) (Table 1). The mean age at breast cancer diagnosis among the cases was $44.1 \pm 11.3$ years while unaffected women were older, with a mean age at interview of $52.2 \pm 13.6$ years. The breast cancer patients were predominantly diagnosed with breast cancer only (96.5\%), followed by breast and ovarian (2.3\%) (Table 1). Invasive ductal carcinoma was the most common diagnosis in breast cancer patients of both African and non-African ancestry, $81.9 \%$ and $79 \%$ respectively (Table 2 ). The tumor subtypes were classified by immunohistochemistry for expression of hormone receptors (estrogen receptor [ER] and progesterone receptor [PR]) and human epidermal growth factor receptor 2 (HER2) (Table 2). If HER2 was classified as negative by immunohistochemistry, additional analysis was performed by using fluorescent in situ hybridization. The ER+/PR+/HER2- was the most common classification, followed by ER+/PR-/HER2-, triple-negative and HER2-enriched $(41.6 \%, 16.2 \%, 15.5 \%$, and $10.4 \%$ respectively).

\section{Spectrum of pathogenic variants in breast cancer susceptibility genes}

Thirty-seven loss-of-function variants (30 distinct variants) were found in 36 breast cancer patients, one of whom carried both BARD1:C.1921C>T and BRCA2:c.3860delA(Fig. 1, Table 2 and Supplementary Table 1). In the cohort of cancer-free women, only one individual carried a pathogenic variant, RAD51C.c.264_265insA. Among self-reported African-descended breast cancer patients, $24.1 \%$ (28 of 116$)$ carried 29 pathogenic variants in ATM, $B A R D 1, B R C A 1, B R C A 2, B R I P 1, F A M 175 A, F A N C M, P A L B 2$ and TP53 genes. The majority of pathogenic variants were found in $B R C A 1$ and $B R C A 2$ (65.5\%, 19 of 29). Four recurrent loss-of-function variants were detected in 11 African-descended breast cancer cases, BRCA1:c.3331delCAAG, BRCA1:c.211A>G, BRCA2:c.1389_1390delAG and PALB2:c.1671_1674delTATT (Table 2). Pathogenic variants were found in BRCA1, BRIP1, NBN, PALB2 and SLX4 genes among eight cases of non-African ancestry $(14.0 \%, 8$ of 57$)$, with $B R C A 1$ and $B R I P 1$ were the most commonly mutated genes (50\%, 4 of 8$)($ Table 2$)$.

Interestingly, compared to previously published annotations, we did not observe any African-specific pathogenic variants as the mutational spectrum was heterogeneous. Moreover, there was no significant statistical association with triple-negative cancer or other specific breast cancer subtype (Supplementary Fig. 1). In Supplementary Fig. 2 we describe in detail the BRCA1 and BRCA2 mutational spectrum of the study population compared with other Black women across the African Diaspora and White women in the literature [16-21].

\section{Performance of breast cancer risk prediction models}

Using different risk models for pathogenic BRCA1 and BRCA2 including the Myriad Risk, the PENN II Risk and BRCAPRO models, we observed that the predicted risk was higher in breast cancer cases carrying germline loss-of-function variants in $B R C A 1$ and/or $B R C A 2$ than in other breast cancer genes, or those carrying wild-type genes (Supplementary Table 2). In the ROC analysis, there was no separation between $B R C A 1$ and $B R C A 2$ carriers and individuals carrying pathogenic variants in other breast cancer genes ( $p>0.05)$. Therefore, we divided our study participants into three genomically stratified groups: highrisk cases (who carried pathogenic variants in breast cancer genes), low-risk cases (who did not carry any pathogenic variants), and cancer-free women. The values of AUC of the risk prediction tools improved slightly for discriminating the high-risk cases from low-risk patients (Fig. 2a): Myriad Risk - 0.66 ( $95 \%$ Cl: 0.55 - 0.76), PENN II BRCA1 - 0.62 (95\% Cl: 0.52 - 0.73), PENN II BRCA2 - 0.59 (95\% Cl: 0.49 - 0.69), BRCAPRO BRCA1 - 0.60 (95\% Cl: 0.47 - 0.70$)$ and BRCAPRO BRCA2 - 0.60 (95\% Cl: $0.49-0.71)$. When the high-risk group was compared with low-risk group and cancer-free women, the power of the risk models to discriminate high-risk individuals from low-risk was increased (Fig. 2b), with Myriad Risk - 0.78 (95\% Cl: $0.70-0.86$ ), PENN II BRCA1 - 0.77 (95\% Cl: 0.69 - 0.85), PENN II BRCA2 - 0.75 (95\% Cl: 0.67 - 0.83), BRCAPRO BRCA1 - 0.72 (95\% Cl: 0.62 - 0.81 ) and BRCAPRO BRCA2 - 0.73 (95\% Cl: 0.64 - 0.82 ), supporting the use of these models in this population. 


\section{Discussion}

Little is known about the genetic susceptibility to breast cancer of African-descended Brazilian women, an understudied population. As there is a high degree of genetic admixture among Brazilian populations [22-24], we sought to study the genetic susceptibility to breast cancer in one of the largest Africandescended populations in Latin America, the inhabitants of the State of Bahia in the Northeast region of Brazil.

Using the validated BROCA panel we identified 36 distinct pathogenic variants in 30 patients with breast cancer cases and only one pathogenic variant in cancer-free women. As observed in previous studies worldwide [4, 21, 25], BRCA1 and BRCA2 were the most frequently mutated genes in breast cancer patients, and their mutation frequencies in women from the Northeast region of Brazil are closer to that in Africans than the reported frequencies in AfricanAmericans and women of European ancestry (Table 3). We compared our results with the BRCA1 and BRCA2 mutational spectrum reported by the Brazilian Consortium of Hereditary Cancer [17], as well as other studies [16, 18-21]. Among sixteen BRCA1 and BRCA2 pathogenic variants detected in Africandescended breast cancer patients in this study, twelve were documented globally, five were found in self-reported African ancestry individuals in non-African countries/regions, one was found in self-reported African ancestry individuals in African countries, eight were previously reported among Brazilians, and one was newly identified (Supplementary Fig. 2). Given the diversity in the African Diaspora and the ancestral heterogeneity of the Brazilian population, it was not surprising that we did not identify more BRCA1 and BRCA2 African founder mutations than European founder mutations [17, 26].

In this study, other genes frequently mutated were the high-risk gene PALB2, as well as ATM and BRIP1, each found in $1.7 \%$ of the cases. Although the prevalence of pathogenic variants in these genes varies in breast cancer patients of African ancestry [6, 7], it confirms that genes involved in DNA repair pathways are the major contributors to inherited breast cancer. Thus, their critical role in understudied populations with high burden of young onset breast cancer deserves further examination. In the South and Southeast regions of Brazil, TP53 is the third gene most frequently mutated among breast cancer patients. Among these patients, most carry TP53:c.1010G>A, which has a known founder effect in those regions of Brazil. However, this pathogenic variant was quite rare $(0.6 \%, 1$ of 173$)$ among the breast cancer cases from the Northeast region of Brazil in our study (Fig. 1 and Table 2).

The spectrum of founder mutations found in our cohort reflects the degree of ancestral admixture within the State of Bahia, where there is a significant history of immigration from Spain, Central Europe and West Africa [22, 26, 27]. Four recurrent variants were discovered among unrelated African-descended breast cancer patients : BRCA1:c.3331delCAAG, BRCA1:c.211A>G, BRCA2:c.1389_1390delAG, and PALB2:c.1671_1674delTATT. The first two were previously described in Spanish descendants [28,29] and in the Northeast Brazilian population [26]. BRCA2:c.1389_1390delAG was described in diverse populations in Central Europe [30-32], while PALB2:c.1671_1674delTATT remains uncharacterized and was documented only twice in ClinVar. To confirm whether this PALB2 pathogenic variant has a founder effect, further studies are needed to evaluate the carriers' haplotypes. In addition, we observed variants that are recurrent in African populations: ATM:c.7913G>A [33, 34], BRCA1:c.824_825dupAGCCATGTGG [35, 36], BRCA2:c.9945delA [37] and FAM175A:c.1011delA [37]. To evaluate performance of risk assessment tools, we next evaluated cancer risk assessment tools like Myriad Risk, the PENN II Risk and BRCAPRO that are used worldwide. In the present study, they demonstrated an overall moderate efficiency at detecting high-risk individuals (Fig. 2 and Supplementary Table 2). Larger population studies are needed to validate our findings to further improve the utility of risk prediction models in diverse populations.

The limitations of this study include the relatively small sample size, the lack of data on genetic ancestry, and the fact that this study used convenient samples that may not reflect population rates. However, this study sought to investigate whether the high mutation rates observed in Nigeria, Cameroon and Uganda are also present in Brazilian women of African ancestry using a validated multi-gene panel. As costs of genomic testing continues to drop, this study provides additional evidence in support of broader access to genetic testing for previously underserved and understudied Black women at high risk of young onset and aggressive forms of breast cancer. The fact that one in five patients carried a loss-of-function variant in BRCA1, BRCA2 or another breast cancer gene with a highly heterogeneous mutational spectrum underscores the importance of utilizing next-generation sequencing-based testing to develop screening and risk-reducing strategies in Northeast Brazil.

\section{Declarations}

\section{Funding}

This work was supported by Coordenação de Aperfeiçoamento de Pessoal de Nível Superior (Código de Financiamento - 001) (G.E.S.F.), American Cancer Society (O.I.O., M.-C.K.) and the John and Editha Kapoor Charitable Foundation (O.I.O., M.-C.K.), Susan G. Komen for the Cure (SAC110026 to O.I.O.), National Cancer Institute Specialized Programs of Research Excellence (SPORE) planning grant (P20CA233307 to 0.I.0), Secretaria de Saúde do Estado da Bahia (I.L.O.N.) and Fundação de Apoio à Pesquisa e Extensão - FAPEX (R.M.). Y.Z. was supported by Paul Calabresi Career Development Award for Clinical Oncology (K12 CA139160 to O.I.O.).

\section{Conflicts of interest/Competing interests}

Olufunmilayo I. Olopade is a cofounder at CancerlQ and has equity in Tempus and 54gene. Tom Walsh consults for Color Genomics. The other authors made no disclosures.

\section{Availability of data and material}

All data described and analyzed here are available upon request.

\section{Code availability}

Not applicable 


\section{Authors' contributions}

Conception and design: Gabriela ES Felix, Rodrigo Santa Cruz Guindalini, Olufunmilayo I Olopade, Ivana Lucia de Oliveina Nascimento, Kiyoko Abe-Sandes, and Mary-Claire King

Financial support: Gabriela ES Felix, Kyoko-Abe-Sandes, Ivana Lucia de Oliveina Nascimento, Roberto Meyer, Rodrigo Santa Cruz Guindalini, Mary-Claire King and Olufunmilayo I. Olopade

Provision of study materials or patients: Gabriela ES Felix, Juliana Côrtes, Taisa Manuela Machado Lopes, Polyanna Carôzo, Irlânia Santos, Thaís Ferreira Bonfim, Betânia Pereira Toralles, Roberto Meyer, Kiyoko Abe-Sandes, Ivana Lucia de Oliveira Nascimento and Olufunmilayo I. Olopade

Collection and assembly of data: Gabriela E.S. Felix, Yonglan Zheng, Jing Zhang, Polyanna Carôzo, Juliana Côrtes and Taisa Manuela Machado Lopes

Data analysis and interpretation: Tom Walsh, Yonglan Zheng, Gabriela E.S. Felix, Rodrigo Santa Cruz Guindalini and Eduardo Martins Netto

Manuscript writing: Gabriela ES Felix, Rodrigo Santa Cruz Guindalini, Yonglan Zheng, Elisabeth Sveen, Ivana Lucia de Oliveina Nascimento, Kiyoko AbeSandes, Mary-Claire King and Olufunmilayo I. Olopade

Final approval of manuscript: All authors

\section{Ethics approval}

This research was approved by research ethics committees or institutional review boards of all participating institutions in Brazil and United States.

\section{Consent to participate}

All studied subjects gave informed written consent upon enrollment in the study.

\section{Consent for publication}

All studied subjects and researchers involved in this study consent to publishing the data.

\section{Acknowledgements}

We would like to thank all subjects who participated in this study, as all the institutions and supporting agencies that made this work possible.

\section{References}

1. Bray F, Ferlay J, Soerjomataram I, Siegel RL, Torre LA, Jemal A (2018) Global cancer statistics 2018: GLOBOCAN estimates of incidence and mortality worldwide for 36 cancers in 185 countries. CA Cancer J Clin 68(6): 394-424. https://doi.org/10.3322/caac.21492

2. Servick K (2014) Breast cancer. Breast cancer: a world of differences. Science 343(6178): 1452-1453. https://doi.org/10.1126/science.343.6178.1452

3. Harford JB (2011) Breast-cancer early detection in low-income and middle-income countries: do what you can versus one size fits all. Lancet Oncol 12(3): 306-312. https://doi.org/10.1016/S1470-2045(10)70273-4

4. Felix GES, Zheng Y, Olopade OI (2018) Mutations in context: implications of BRCA testing in diverse populations. Fam Cancer 17(4): 471-483. https://doi.org/10.1007/s10689-017-0038-2

5. Walsh T, Lee MK, Casadei S, et al. (2010) Detection of inherited mutations for breast and ovarian cancer using genomic capture and massively parallel sequencing. Proc Natl Acad Sci U S A 107(28): 12629-12633. https://doi.org/10.1073/pnas.1007983107

6. Churpek JE, Walsh T, Zheng Y, et al. (2015) Inherited predisposition to breast cancer among African American women. Breast Cancer Res Treat 149(1): 3139. https://doi.org/10.1007/s10549-014-3195-0

7. Zheng Y, Walsh T, Gulsuner S, et al. (2018) Inherited Breast Cancer in Nigerian Women. J Clin Oncol 36(28): 2820-2825. https://doi.org/10.1200/JCO.2018.78.3977

8. Adedokun B, Zheng Y, Ndom P, et al. (2019) Prevalence of Inherited Mutations in Breast Cancer Predisposition Genes among Uganda and Cameroon Women. Cancer Epidemiol Biomarkers Prev 29(2):359-367. https://doi.org/10.1158/1055-9965.EPI-19-0506

9. Orlandini LF, Antonio M, Espreafico CR, Jr., et al. (2021) Epidemiological Analyses Reveal a High Incidence of Breast Cancer in Young Women in Brazil. JCO Glob Oncol 7: 81-88. https://doi.org/10.1200/G0.20.00440

10. Moura RR, Coelho AV, Balbino Vde Q, Crovella S, Brandao LA (2015) Meta-analysis of Brazilian genetic admixture and comparison with other Latin America countries. Am J Hum Biol 27(5): 674-680. https://doi.org/10.1002/ajhb.22714

11. Frank TS, Deffenbaugh AM, Reid JE, et al. (2002) Clinical characteristics of individuals with germline mutations in BRCA1 and BRCA2: analysis of 10,000 individuals. J Clin Oncol 20(6): 1480-1490. https://doi.org/10.1200/JC0.2002.20.6.1480

12. Lindor NM, Johnson KJ, Harvey H, et al. (2010) Predicting BRCA1 and BRCA2 gene mutation carriers: comparison of PENN II model to previous study. Fam Cancer 9(4): 495-502. https://doi.org/10.1007/s10689-010-9348-3

13. Berry DA, Iversen ES, Jr., Gudbjartsson DF, et al. (2002) BRCAPRO validation, sensitivity of genetic testing of BRCA1/BRCA2, and prevalence of other breast cancer susceptibility genes. J Clin Oncol 20(11): 2701-2712. https://doi.org/10.1200/JC0.2002.05.121 
14. Walsh T, Casadei S, Lee MK, et al. (2011) Mutations in 12 genes for inherited ovarian, fallopian tube, and peritoneal carcinoma identified by massively parallel sequencing. Proc Natl Acad Sci U S A 108(44): 18032-18037. https://doi.org/10.1073/pnas.1115052108

15. Nord AS, Lee M, King MC, Walsh T (2011) Accurate and exact CNV identification from targeted high-throughput sequence data. BMC Genomics 12 : 184. https://doi.org/10.1186/1471-2164-12-184

16. Silva FC, Lisboa BC, Figueiredo MC, et al. (2014) Hereditary breast and ovarian cancer: assessment of point mutations and copy number variations in Brazilian patients. BMC Med Genet 15: 55. https://doi.org/10.1186/1471-2350-15-55

17. Palmero El, Carraro DM, Alemar B, et al. (2018) The germline mutational landscape of BRCA1 and BRCA2 in Brazil. Sci Rep 8(1): 9188. https://doi.org/10.1038/s41598-018-27315-2

18. Rebbeck TR, Friebel TM, Friedman E, et al. (2018) Mutational spectrum in a worldwide study of 29,700 families with BRCA1 or BRCA2 mutations. Hum Mutat 39(5): 593-620. https://doi.org/10.1002/humu.23406

19. Cotrim DP, Ribeiro ARG, Paixao D, et al. (2019) Prevalence of BRCA1 and BRCA2 pathogenic and likely pathogenic variants in non-selected ovarian carcinoma patients in Brazil. BMC Cancer 19(1): 4. https://doi.org/10.1186/s12885-018-5235-3

20. Friebel TM, Andrulis IL, Balmana J, et al. (2019) BRCA1 and BRCA2 pathogenic sequence variants in women of African origin or ancestry. Hum Mutat 40(10): 1781-1796. https://doi.org/10.1002/humu.23804

21. Palmer JR, Polley EC, Hu C, et al. (2020) Contribution of Germline Predisposition Gene Mutations to Breast Cancer Risk in African American Women. J Natl Cancer Inst 112(12): 1213-1221. https://doi.org/10.1093/jnci/djaa040

22. Lima-Costa MF, Rodrigues LC, Barreto ML, et al. (2015) Genomic ancestry and ethnoracial self-classification based on 5,871 community-dwelling Brazilians (The Epigen Initiative). Sci Rep 5: 9812. https://doi.org/10.1038/srep09812

23. Magalhaes da Silva T, Sandhya Rani MR, de Oliveira Costa GN, et al. (2015) The correlation between ancestry and color in two cities of Northeast Brazil with contrasting ethnic compositions. Eur J Hum Genet 23(7): 984-989. https://doi.org/10.1038/ejhg.2014.215

24. Felix GES, Abe-Sandes K, Bonfim TM, et al. (2010) Ancestry informative markers and complete blood count parameters in Brazilian blood donors. Revista Brasileira de Hematologia e Hemoterapia 32(4): 282-285. https://doi.org/10.1590/S1516-84842010005000074

25. Hu C, Hart SN, Gnanaolivu R, et al. (2021) A Population-Based Study of Genes Previously Implicated in Breast Cancer. N Engl J Med 384(5): $440-451$. https://doi.org/10.1056/NEJMoa2005936

26. Felix GE, Abe-Sandes C, Machado-Lopes TM, et al. (2014) Germline mutations in BRCA1, BRCA2, CHEK2 and TP53 in patients at high-risk for HBOC: characterizing a Northeast Brazilian Population. Hum Genome Var 1: 14012. https://doi.org/10.1038/hgv.2014.12

27. Kehdy FS, Gouveia MH, Machado M, et al. (2015) Origin and dynamics of admixture in Brazilians and its effect on the pattern of deleterious mutations. Proc Natl Acad Sci U S A 112(28): 8696-8701. https://doi.org/10.1073/pnas.1504447112

28. Blay P, Santamaria I, Pitiot AS, et al. (2013) Mutational analysis of BRCA1 and BRCA2 in hereditary breast and ovarian cancer families from Asturias (Northern Spain). BMC Cancer 13: 243. https://doi.org/10.1186/1471-2407-13-243

29. Vega A, Campos B, Bressac-De-Paillerets B, et al. (2001) The R71G BRCA1 is a founder Spanish mutation and leads to aberrant splicing of the transcript. Hum Mutat 17(6): 520-521. https://doi.org/10.1002/humu.1136

30. Foretova L, Machackova E, Navratilova M, et al. (2004) BRCA1 and BRCA2 mutations in women with familial or early-onset breast/ovarian cancer in the Czech Republic. Hum Mutat 23(4): 397-398. https://doi.org/10.1002/humu.9226

31. Goelen G, Teugels E, Bonduelle M, Neyns B, De Greve J (1999) High frequency of BRCA1/2 germline mutations in 42 Belgian families with a small number of symptomatic subjects. J Med Genet 36(4): 304-308

32. Machackova E, Foretova L, Lukesova M, et al. (2008) Spectrum and characterisation of BRCA1 and BRCA2 deleterious mutations in high-risk Czech patients with breast and/or ovarian cancer. BMC Cancer 8: 140. https://doi.org/10.1186/1471-2407-8-140

33. Coutinho G, Mitui M, Campbell C, et al. (2004) Five haplotypes account for fifty-five percent of ATM mutations in Brazilian patients with ataxia telangiectasia: seven new mutations. Am J Med Genet A 126A(1): 33-40. https://doi.org/10.1002/ajmg.a.20570

34. Demuth I, Dutrannoy V, Marques W, Jr., et al. (2011) New mutations in the ATM gene and clinical data of 25 AT patients. Neurogenetics $12(4)$ : $273-282$. https://doi.org/10.1007/s10048-011-0299-0

35. Zhang J, Fackenthal JD, Zheng Y, et al. (2012) Recurrent BRCA1 and BRCA2 mutations in breast cancer patients of African ancestry. Breast Cancer Res Treat 134(2): 889-894. https://doi.org/10.1007/s10549-012-2136-Z

36. Hall MJ, Reid JE, Burbidge LA, et al. (2009) BRCA1 and BRCA2 mutations in women of different ethnicities undergoing testing for hereditary breastovarian cancer. Cancer 115(10): 2222-2233. https://doi.org/10.1002/cncr.24200

37. Lek M, Karczewski KJ, Minikel EV, et al. (2016) Analysis of protein-coding genetic variation in 60,706 humans. Nature 536(7616): $285-291$. https://doi.org/10.1038/nature19057

\section{Tables}

Table 1. Characteristics of Brazilian cases and unaffected volunteers. 


\begin{tabular}{|c|c|c|c|}
\hline \multicolumn{2}{|l|}{ Characteristic } & $\begin{array}{l}\text { Cases }(n=173) \\
N(\%)\end{array}$ & $\begin{array}{l}\text { Unaffected volunteers }(n=119) \\
N(\%)\end{array}$ \\
\hline \multirow[t]{3}{*}{ Age (years) } & $\leq 50$ & $131(79.3 \%)$ & $50(42.01 \%)$ \\
\hline & $>50$ & $42(20.7 \%)$ & $69(57.9 \%)$ \\
\hline & Mean \pm SD & $44.1 \pm 11.3$ & $52.2 \pm 13.6$ \\
\hline \multirow[t]{3}{*}{ Type of cancer } & Breast only & 167 (96.5\%) & - \\
\hline & Breast and Ovarian & $4(2.3 \%)$ & - \\
\hline & Other & $2(1.2 \%)$ & - \\
\hline \multirow[t]{3}{*}{ Self-reported ancestry } & White & $45(26 \%)$ & $10(8.4 \%)$ \\
\hline & African-descended & $116(67 \%)$ & $108(90.8 \%)$ \\
\hline & Other & $12(6.9 \%)$ & $1(0.8 \%)$ \\
\hline \multirow[t]{2}{*}{ Family history of cancer } & Yes & $111(64.2 \%)$ & 47 (39.5\%) \\
\hline & No & $62(35.8 \%)$ & $72(60.5 \%)$ \\
\hline
\end{tabular}

Table 2. Spectrum of pathogenic variants in breast cancer susceptibility genes among Brazilian cases. 


\begin{tabular}{|c|c|c|c|c|c|c|c|c|c|c|}
\hline ID & Variant & $\begin{array}{l}\text { Type of } \\
\text { cancer }\end{array}$ & $\begin{array}{l}\text { Age at } \\
\text { diagnosis }\end{array}$ & $\begin{array}{l}\text { Self- } \\
\text { reported } \\
\text { ancestry }\end{array}$ & $\begin{array}{l}\text { Family } \\
\text { history } \\
\text { of } \\
\text { cancer }\end{array}$ & Histology & $\begin{array}{l}\text { Tumor } \\
\text { grade }\end{array}$ & $\begin{array}{l}\text { Tumor } \\
\text { stage }\end{array}$ & ER & PR \\
\hline ACM076 & NBNc.156_157delTT & Breast & 56 & Other & No & IDC & - & T4cN3M1 & Pos & Po \\
\hline ACM088 & BRIP1 c. $1741 \mathrm{C}>\mathrm{T}$ & Breast & 40 & White & No & IDC & IV & T2N1M0 & Pos & Po \\
\hline СМ003 & BRCA2 c.2108delC & Breast & 42 & Other & Yes & IDC & III & T2NOMO & Pos & $\mathrm{Ne}$ \\
\hline СМ023 & $\begin{array}{l}\text { BRCA1 } \\
\text { c.3331_3334delCAAG }\end{array}$ & Breast & 36 & $\begin{array}{l}\text { African- } \\
\text { descended }\end{array}$ & Yes & IDC & I & T1N0M0 & Pos & Po \\
\hline СМ033 & $B R C A 1$ c. $1115 \mathrm{G}>\mathrm{A}$ & $\begin{array}{l}\text { Breast } \\
\text { and } \\
\text { Ovarian }\end{array}$ & 36 & $\begin{array}{l}\text { African- } \\
\text { descended }\end{array}$ & Yes & $\begin{array}{l}\text { IDC + Lobular } \\
\text { carcinoma (Breast); } \\
\text { Serous } \\
\text { adenocarcinoma } \\
\text { (Ovarian) }\end{array}$ & IIB & T2N1M0 & Pos & Po \\
\hline СМ048 & $B R C A 1$ c. $211 \mathrm{~A}>\mathrm{G}$ & Breast & 39 & $\begin{array}{l}\text { African- } \\
\text { descended }\end{array}$ & Yes & $\begin{array}{l}\text { Medullary } \\
\text { carcinoma of the } \\
\text { breast }\end{array}$ & - & - & $\mathrm{Neg}$ & $\mathrm{Ne}$ \\
\hline CM130 & $\begin{array}{l}\text { BRCA1 } \\
\text { c.825_826dupGCCATGTGGA }\end{array}$ & $\begin{array}{l}\text { Breast } \\
\text { and } \\
\text { Thyroid }\end{array}$ & 64 & White & Yes & IDC & - & - & Neg & $\mathrm{Ne}$ \\
\hline CM179 & BRIP1 с. $2392 \mathrm{C}>\mathrm{T}$ & $\begin{array}{l}\text { Breast } \\
\text { and } \\
\text { Ovarian }\end{array}$ & 42 & $\begin{array}{l}\text { African- } \\
\text { descended }\end{array}$ & Yes & Lobular carcinoma & - & - & Pos & Po \\
\hline CM211 & SLX4 c.4828delT & Breast & 28 & White & Yes & DCIS & III & TisNOMO & $\mathrm{Neg}$ & $\mathrm{Ne}$ \\
\hline CM223 & $\begin{array}{l}\text { BRCA1 } \\
\text { c.3331_3334delCAAG }\end{array}$ & Breast & 28 & $\begin{array}{l}\text { African- } \\
\text { descended }\end{array}$ & Yes & IDC & III & T2N0M1 & $\mathrm{Neg}$ & $\mathrm{Ne}$ \\
\hline CM242 & $B R C A 1$ c. $211 \mathrm{~A}>\mathrm{G}$ & Breast & 41 & $\begin{array}{l}\text { African- } \\
\text { descended }\end{array}$ & Yes & $\begin{array}{l}\text { Medullary } \\
\text { carcinoma of the } \\
\text { breast }\end{array}$ & - & - & Neg & $\mathrm{Ne}$ \\
\hline CM247 & $\begin{array}{l}\text { BRCA2 } \\
\text { c.5904_5907delAGTC }\end{array}$ & Breast & 34 & $\begin{array}{l}\text { African- } \\
\text { descended }\end{array}$ & Yes & IDC & II & T2N1M0 & Pos & $\mathrm{Ne}$ \\
\hline CM252 & $B R C A 1$ c. $211 A>G$ & Breast & 52 & $\begin{array}{l}\text { African- } \\
\text { descended }\end{array}$ & Yes & IDC & Ila & T2NOMO & $\mathrm{Neg}$ & $\mathrm{Ne}$ \\
\hline CM266 & PALB2 c.1671_1674delTATT & Breast & 35 & $\begin{array}{l}\text { African- } \\
\text { descended }\end{array}$ & Yes & IDC & - & - & Pos & Po \\
\hline CM277 & PALB2 c.1671_1674delTATT & Breast & 49 & $\begin{array}{l}\text { African- } \\
\text { descended }\end{array}$ & No & IDC & ॥ & - & Pos & Po \\
\hline CM278 & BRIP1 c. $2097+1 \mathrm{G}>\mathrm{C}$ & Breast & 52 & White & Yes & IDC & $\|$ & pT2pN0pMx & Neg & $\mathrm{Ne}$ \\
\hline СМ293 & PALB2 c.355delC & Breast & 49 & White & Yes & IDC & - & - & Pos & Po \\
\hline CM297 & ATM c.3801delG & Breast & 38 & $\begin{array}{l}\text { African- } \\
\text { descended }\end{array}$ & Yes & IDC & - & - & Pos & Po \\
\hline СМ309 & $\begin{array}{l}\text { FANCM } \\
\text { c.5766_5769delGACT }\end{array}$ & Breast & 38 & $\begin{array}{l}\text { African- } \\
\text { descended }\end{array}$ & Yes & IDC & - & - & Pos & Po \\
\hline СM318 & $B R C A 2$ c. $7672 \mathrm{G}>\mathrm{T}$ & Breast & 27 & $\begin{array}{l}\text { African- } \\
\text { descended }\end{array}$ & Yes & DCIS & IV & T3N2M1 & Pos & Po \\
\hline СM322 & FAM175A c. 1011 delA & Breast & 43 & $\begin{array}{l}\text { African- } \\
\text { descended }\end{array}$ & No & IDC & III & pT4pN3 & Pos & $\mathrm{Ne}$ \\
\hline СМ362 & BRCA2 c.1389_1390delAG & Breast & 47 & $\begin{array}{l}\text { African- } \\
\text { descended }\end{array}$ & No & IDC & $\|$ & - & Pos & Po \\
\hline СМ385 & TP53 c. $1010 \mathrm{G}>\mathrm{A}$ & Breast & 28 & $\begin{array}{l}\text { African- } \\
\text { descended }\end{array}$ & Yes & IDC & $\|$ & T1N1M0 & Pos & Po \\
\hline СМ389 & $B R C A 1$ c. $1327 \mathrm{~A}>\mathrm{T}$ & Breast & 34 & $\begin{array}{l}\text { African- } \\
\text { descended }\end{array}$ & Yes & IDC & - & - & $\mathrm{Neg}$ & $\mathrm{Ne}$ \\
\hline CM403 & $B R C A 2 \mathrm{c} .8488-1 \mathrm{G}>\mathrm{A}$ & Breast & 34 & $\begin{array}{l}\text { African- } \\
\text { descended }\end{array}$ & Yes & IDC & $\|$ & T1N0M0 & Pos & $\mathrm{Ne}$ \\
\hline CM420 & $\begin{array}{l}\text { BRCA1 } \\
\text { c.3331_3334delCAAG }\end{array}$ & Breast & 38 & $\begin{array}{l}\text { African- } \\
\text { descended }\end{array}$ & Yes & IDC & $\|$ & T2NOMO & - & - \\
\hline CM440 & BRCA2 c.736delT & Breast & 42 & $\begin{array}{l}\text { African- } \\
\text { descended }\end{array}$ & Yes & IDC & IV & $\mathrm{T} 4 \mathrm{cN} 2 \mathrm{MX}$ & Pos & Po \\
\hline CM512 & ATM c. $7913 \mathrm{G}>\mathrm{A}$ & Breast & 38 & African- & Yes & IDC & $\|$ & T1N1M0 & Pos & Po \\
\hline
\end{tabular}




\begin{tabular}{|c|c|c|c|c|c|c|c|c|c|c|}
\hline & & & & descended & & & & & & \\
\hline CM243 & BRCA1 c.470_471delCT & Breast & 60 & White & Yes & IDC & - & - & Neg & $\mathrm{Ne}$ \\
\hline CM536 & BRCA2 c.1389_1390delAG & Breast & 46 & $\begin{array}{l}\text { African- } \\
\text { descended }\end{array}$ & Yes & IDC & ॥ & T1N0M0 & Neg & Po: \\
\hline CM550 & $\begin{array}{l}\text { BRCA1 } \\
\text { c.3331_3334delCAAG }\end{array}$ & Breast & 26 & $\begin{array}{l}\text { African- } \\
\text { descended }\end{array}$ & No & IDC & II & pT3pN3a & Neg & $\mathrm{Ne}$ \\
\hline CM564 & $B R C A 1$ c. $5251 \mathrm{C}>\mathrm{T}$ & Breast & 40 & $\begin{array}{l}\text { African- } \\
\text { descended }\end{array}$ & No & IDC & ॥ & - & $\mathrm{Neg}$ & $\mathrm{Ne}$ \\
\hline CM575 & $\begin{array}{l}\text { BRCA2 c. } 3860 \text { delA, BARD1 } \\
\text { c. } 1921 \mathrm{C}>\mathrm{T}\end{array}$ & Breast & 41 & $\begin{array}{l}\text { African- } \\
\text { descended }\end{array}$ & Yes & IDC & - & - & - & - \\
\hline CM581 & $B R C A 2$ c. $6938-1 \mathrm{G}>\mathrm{C}$ & Breast & 43 & $\begin{array}{l}\text { African- } \\
\text { descended }\end{array}$ & Yes & IDC & II & T2NOMO & Pos & Po: \\
\hline CM582 & $B R C A 2 \mathrm{c} .2 \mathrm{~T}>\mathrm{G}$ & $\begin{array}{l}\text { Breast } \\
\text { and } \\
\text { Ovarian }\end{array}$ & 49 & $\begin{array}{l}\text { African- } \\
\text { descended }\end{array}$ & No & $\begin{array}{l}\text { IDC (Breast) and } \\
\text { Serous papillary } \\
\text { cystadenocarcinoma } \\
\text { (Ovarian) }\end{array}$ & $\begin{array}{l}\text { lb } \\
\text { (breast) } \\
\text { / III } \\
\text { (ovarian) }\end{array}$ & T2NOMO & - & - \\
\hline CM590 & ATM c.8264_8268delATAAG & Breast & 41 & $\begin{array}{l}\text { African- } \\
\text { descended }\end{array}$ & Yes & - & - & - & - & - \\
\hline
\end{tabular}

ER, estrogen receptor; DCIS, ductal carcinoma in situ; IDC, invasive ductal carcinoma; HER2, human epidermal growth factor receptor 2; Pos, positive; PR, progesterone receptor; and Neg, negative.

Table 3. Comparison of the high-risk mutational profile among Black women across the African Diaspora and White women.

\begin{tabular}{|c|c|c|c|c|c|c|c|c|c|c|}
\hline \multirow{2}{*}{$\begin{array}{l}\text { Study } \\
\text { population } \\
\text { Case/Control }\end{array}$} & \multicolumn{2}{|c|}{ Brazilian (this study) } & \multicolumn{2}{|c|}{ Nigerian (ref. 7) } & \multicolumn{2}{|c|}{$\begin{array}{l}\text { Cameroonian and } \\
\text { Ugandan (ref. 8) }\end{array}$} & \multicolumn{2}{|c|}{$\begin{array}{l}\text { African American } \\
\text { (ref. 21) }\end{array}$} & \multicolumn{2}{|c|}{ CARRIERS (ref. 25) } \\
\hline & Case & $\begin{array}{l}\text { Unaffected } \\
\text { volunteers }\end{array}$ & Case & Control & Case & Control & Case & Control & Case & Control \\
\hline $\begin{array}{l}\text { Number of } \\
\text { individuals }\end{array}$ & $\begin{array}{l}173(67 \% \\
\text { Black) }\end{array}$ & $\begin{array}{l}119(90.8 \% \\
\text { Black) }\end{array}$ & 1,136 & 997 & 196 & 185 & 5,054 & 4,993 & $\begin{array}{l}32,247 \text { (78.9\% } \\
\text { White) }\end{array}$ & $\begin{array}{l}32,544(76.2 \% \\
\text { White) }\end{array}$ \\
\hline $\begin{array}{l}\text { Ave. age } \\
\text { (years) }\end{array}$ & 44.1 & 52.2 & 47.5 & 47 & 46.2 & 46.6 & 54.4 & 55.2 & 62.1 & 61.2 \\
\hline$B R C A 1$ & $12(6.9 \%)$ & 0 & $\begin{array}{l}80 \\
(7.0 \%)\end{array}$ & $\begin{array}{l}3 \\
(0.3 \%)\end{array}$ & $11(5.6 \%)$ & $2(1.1 \%)$ & $\begin{array}{l}81 \\
(1.6 \%)\end{array}$ & $\begin{array}{l}1 \\
(0.02 \%)\end{array}$ & $275(0.9 \%)$ & $37(0.1 \%)$ \\
\hline$B R C A 2$ & $10(5.8 \%)$ & 0 & $\begin{array}{l}47 \\
(4.1 \%)\end{array}$ & $\begin{array}{l}4 \\
(0.3 \%)\end{array}$ & $11(5.6 \%)$ & 0 & $\begin{array}{l}98 \\
(1.9 \%)\end{array}$ & $\begin{array}{l}12 \\
(0.2 \%)\end{array}$ & $417(1.3 \%)$ & $78(0.2 \%)$ \\
\hline PALB2 & $3(1.7 \%)$ & 0 & $\begin{array}{l}11 \\
(0.4 \%)\end{array}$ & 0 & $2(1.0 \%)$ & 0 & $\begin{array}{l}53 \\
(1.0 \%)\end{array}$ & $\begin{array}{l}5 \\
(0.1 \%)\end{array}$ & $148(0.5 \%)$ & $38(0.1 \%)$ \\
\hline TP53 & $1(0.6 \%)$ & 0 & $\begin{array}{l}5 \\
(0.4 \%)\end{array}$ & 0 & $1(0.5 \%)$ & 0 & $\begin{array}{l}5 \\
(0.1 \%)\end{array}$ & $\begin{array}{l}1 \\
(0.02 \%)\end{array}$ & $19(0.06 \%)$ & $2(0.01 \%)$ \\
\hline Other genes & $11(6.4 \%)$ & $1(0.8 \%)$ & $\begin{array}{l}24 \\
(2.1 \%)\end{array}$ & $\begin{array}{l}11 \\
(1.1 \%)\end{array}$ & $6(3.1 \%)$ & $1(0.5 \%)$ & $\begin{array}{l}179 \\
(3.5 \%)\end{array}$ & $\begin{array}{l}95 \\
(1.9 \%)\end{array}$ & $762(2.4 \%)$ & $376(1.2 \%)$ \\
\hline
\end{tabular}

\section{Figures}




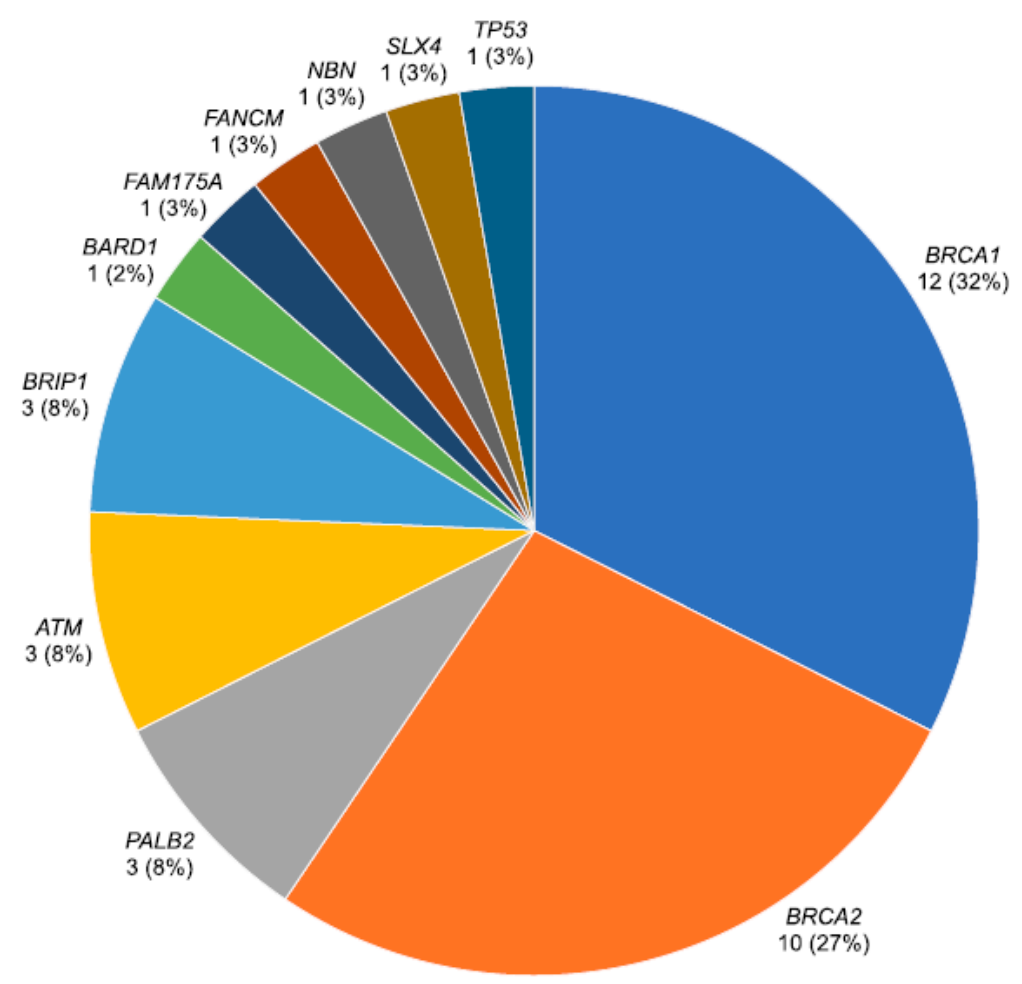

Figure 1

Genes with pathogenic variants in breast cancer patients from the Northeast region of Brazil. A total of 37 pathogenic variants were identified. Number and proportion of pathogenic variant(s) in each gene are shown. 


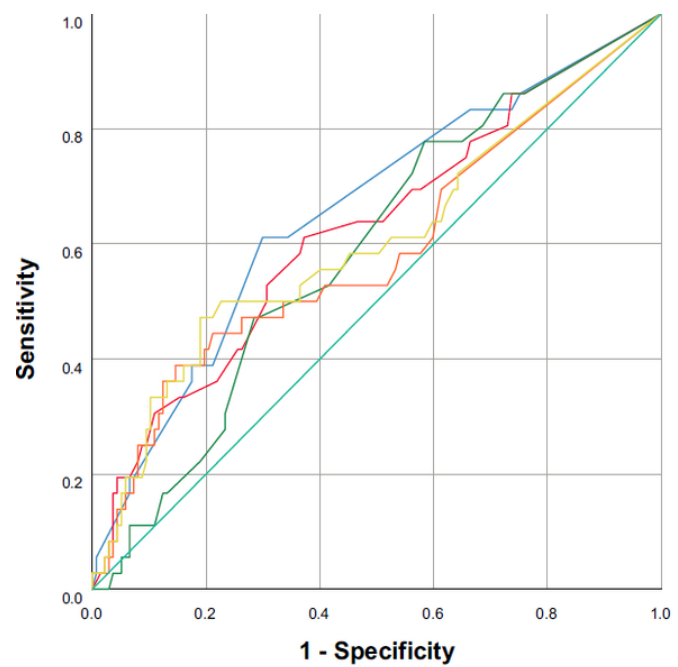

$$
\begin{aligned}
& \text { Myriad (AUC 0.66) } \\
& \text { PENN BRCA1 (AUC 0.62) } \\
& \text { PENN BRCA2 (AUC 0.59) } \\
& \text { BRCAPRO BRCA1 (AUC 0.60) } \\
& \text { BRCAPRO BRCA2 (AUC 0.60) }
\end{aligned}
$$

Reference

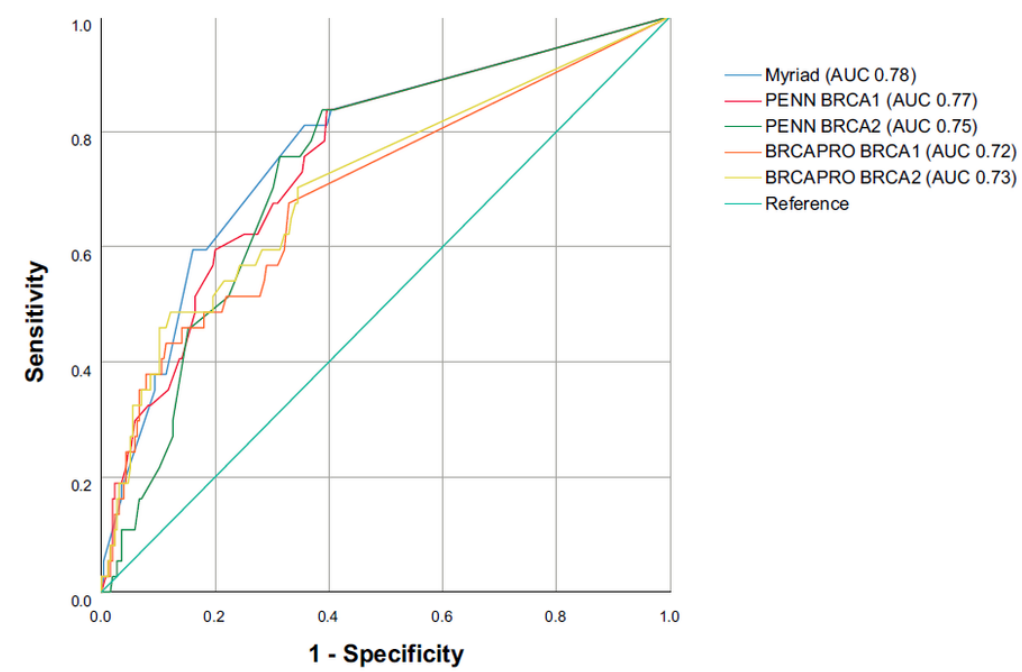

Figure 2

Performance of risk prediction models among (a) high-risk cases and low-risk cases, and (b) high-risk cases, low-risk cases, and cancer-free women. 